\title{
The Impacts of Improving Water Management of Smallholder Agriculture in Ethiopia
}

\author{
Mulat Asmamaw and Ahmed Kurunc ${ }^{\mathrm{a}}$ \\ a Department of Agricultural Structures and Irrigation, Faculty of Agriculture, Akdeniz University, Antalya, 07058, Turkey
}

\begin{abstract}
The purpose of this review is to compile the previous, current, and upcoming trends of water management and irrigation program development to raise crop production and ensure smallholder food security in Ethiopia. Integrated water management and irrigation development have been suggested to be a fundamental crucial part in decreasing food scarcity and alleviating poverty. Several organizations of irrigation schemes in Ethiopia have very weak institutional set up with limited financial and technical capacities and poor performance. Also, the existing performance of agricultural water development is not meaningfully contributing to the national economy of the country comparing to rain-fed farming.
\end{abstract}

Keywords:- Climate change; Food security; Integrated management; Water resource; Soil conservation; Dryland farming; Irrigation scheme.

\section{INTRODUCTION}

Ethiopia is the second-most populated country in Africa, with a projected the population of about 110 million which increases annually at about $2.4 \%$ (Worldometers, 2019). To meet the food requirements of its fast-increasing population, the country needs to double its cereal production by 2025. Agriculture is the major sector of the economy contributing about $43 \%$ of the country's gross domestic product and engaging more than $85 \%$ of the population (Eneyew et al., 2014). The majority of the poverty-stricken people in Ethiopia directly or indirectly rely on rain-fed smallholder agriculture for their incomes even though distribution and intensity of rainfall vary considerably, resulting in incidents of drought every four to five years. Despite this fact, about $95 \%$ of the country's farm production is done by smallholder farmers (FAO, 2015), that hold less than one hectare of agricultural land. Also, average harvests per hectare are also little. According to Eneyew et al. (2015), low productivity resulted from the use of backward technology and unimproved inputs for productivity-enhancement. These characteristic impacts on food production are closely related to the persistence of poverty in all rural areas of Ethiopia (FAO, 2015). Smallholder agriculture, thus, is a pertinent and potentially worthwhile implement for minimizing poverty and maintaining domestic food security in these parts (Tadesse and Baihilu, 2017).
Indeed, Ethiopia has abundant water resources that could be used for, among other things, irrigation, to delink the performance of the economy from rainfall variability (Makombe et al., 2017). In general statuses, Ethiopia is far from being the country with the most water shortage in the world. World Bank figures show that in 2009, Ethiopia had $1,502 \mathrm{~m}^{3}$ of "renewable internal water resources" obtainable per person as compared, for example, to 1,430 $\mathrm{m}^{3}$ in Turkey, $1,306 \mathrm{~m}^{3}$ in Germany, $1,086 \mathrm{~m}^{3}$ in Denmark, $714 \mathrm{~m}^{3}$ in Bangladesh, $322 \mathrm{~m}^{3}$ in Pakistan, $100 \mathrm{~m}^{3}$ in Israel and just $22 \mathrm{~m}^{3}$ in Egypt. The country has 12 main river basins and 12 large lakes, and the total yearly surface runoff is estimated at 122 billion $\mathrm{m}^{3}$ (Evans, 2012). Although Ethiopia earned the term "water tower of Eastern Africa", the population remains without proper water infrastructure, and smallholder agriculture's poverty lessening results have been unsatisfactory (Stokes et al., 2010). In this regard, the World Bank reports that the present stages of irrigation in Ethiopia signify less than 5 to $10 \%$ of the potential 5.3 million hectares of irrigable land in the country (Evans, 2012).

Currently, the continuing frequent effects of drought, water shortage, erosion, flood, salinity, and unpredictable rain are the most crucial food security aid facing in the country (Asmamaw et al., 2018; Tadesse and Baihilu, 2017). If production falls, subsistence farmers have insufficient or no substitute income to supply food for their families. When alternatives exhausted, the poor are enforced to exploit land resources, including fragile ones to survive, and it turns out that they are both the sufferers and willing agents of environmental degradation and deforestation (Tadesse and Baihilu, 2017). Consequently, the Ethiopian government has been trying to alter from outdated and labor-intensive, rain-fed, supply-oriented, and production-driven farming to technology-intensive automated, irrigated and, market-driven ones (Yihdego and Ghosal, 2016). However, several organizations of irrigation schemes in the country have very restricted monetary and technical capacities and poor presentation (Haileslassie et al., 2016).

Despite the poor performance, irrigation practices in the country have allowed some smallholders to expand their agricultural schemes and produce high-value products for local and even worldwide markets (Evans, 2012). On the other hand, it has been investigated that average crop yield per household for some of the major cereals and horticultural crops was highest for irrigation users than non-users (Eneyew et al., 2014). In this regard, the succession of studies showed that irrigation is critical to increasing smallholder income since it can help farmers to 
rise diversity and yield of crops, and extend their farming season (Bacha et al., 2011; Dauda et al., 2009; FAO, 2011; Kuwornu and Owusu, 2012).

Although there is a common understanding of agricultural water management practices, such as water conservation, water harvesting, irrigation, and drainage to improve food security, little is recognized about the comprehensive ways of its impact on smallholders' agriculture in Ethiopia. This shows there is a scanty of assessments of the potentials and studies made on integrated water management (IWM) in different parts of the country. This information goes significant in such a way that the participants and government become aware of what has been done in the past in this sector. Therefore, the target of this paper is to review various articles reported worldwide, and particularly Ethiopia for further information concerning the impacts of improving irrigation water management of smallholder agriculture.

\section{SOME SELECTED CHALLENGES TO FOOD SECURITY OF SMALLHOLDERS IN ETHIOPIA}

\begin{abstract}
$>$ Drought
A rise in susceptibility to drought threats may result from a frequent occurrence and harshness of drought, higher societal vulnerability, or an amalgamation of the two (Shiferaw et al., 2014). Ethiopia is heavily dependent on agriculture, and as its agriculture is mainly rain-fed, the economy is remarkably vulnerable to bad climate. Precipitation in Ethiopia is very unpredictable, and most rains fall severely, often as heavy tempests, with very excessive intensity and high spatial and temporal inconsistency. In general, the southwestern part of the country receives the highest amount of rainfall up to 2000 $\mathrm{mm}$ on annual basis compared to the eastern lowlands that only receive around $400 \mathrm{~mm}$ (Figure 1) (Rosell, 2014). These drylands harbor one-third of the Ethiopian population and this number is continuously increasing as more and more people migrate from highly degraded highland areas into the drylands (Georgis, 2014). The reliance on rain-fed farming combined with the unpredictable nature of rain is the foremost factor responsible for the low performance of the agrarian sector (Awulachew, 2010) for the extremely high risk of yearly and intra-seasonal droughts (Evans, 2012).
\end{abstract}

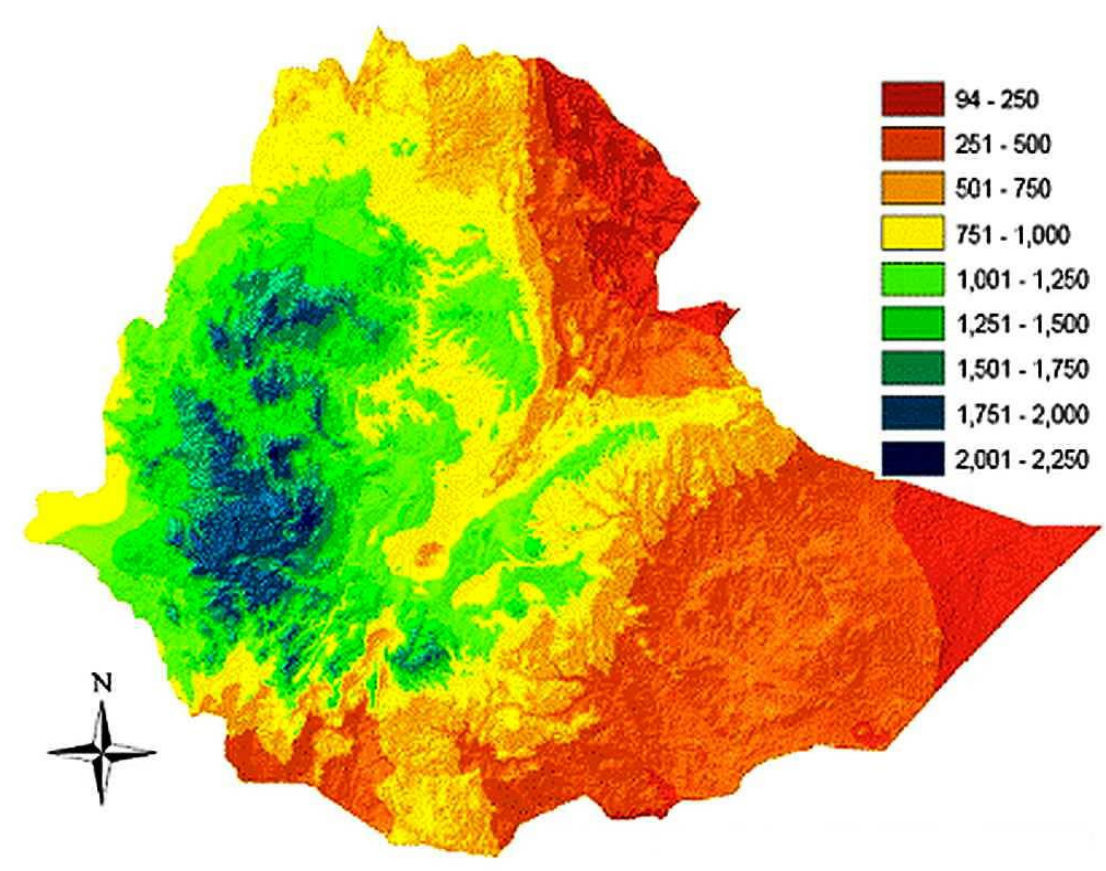

Fig 1:- Mean annual rainfall distribution in Ethiopia (Rosell, 2014)

By means of a drought vulnerability indicator (DVI) calculated at the country level, Ethiopia is classified as one of the nations with high comparative susceptibility to drought (Naumann et al., 2014). Because of the higher reliance on rain-fed cultivation, about $75 \%$ of the land in Ethiopia is exposed to recurrent and serious droughts (Shiferaw et al., 2014). Drought happens wherever in the glob but its impairment is not as serious as in Africa, particularly in Ethiopia, and has frequently led to an unexpected reduction of agricultural GDP in the country. In Ethiopia, there is a correlation between GDP growth and the amount of rainfall in a year, as it has been seen, for example in (1999-2000) (Figure 2) (Evans, 2012). 


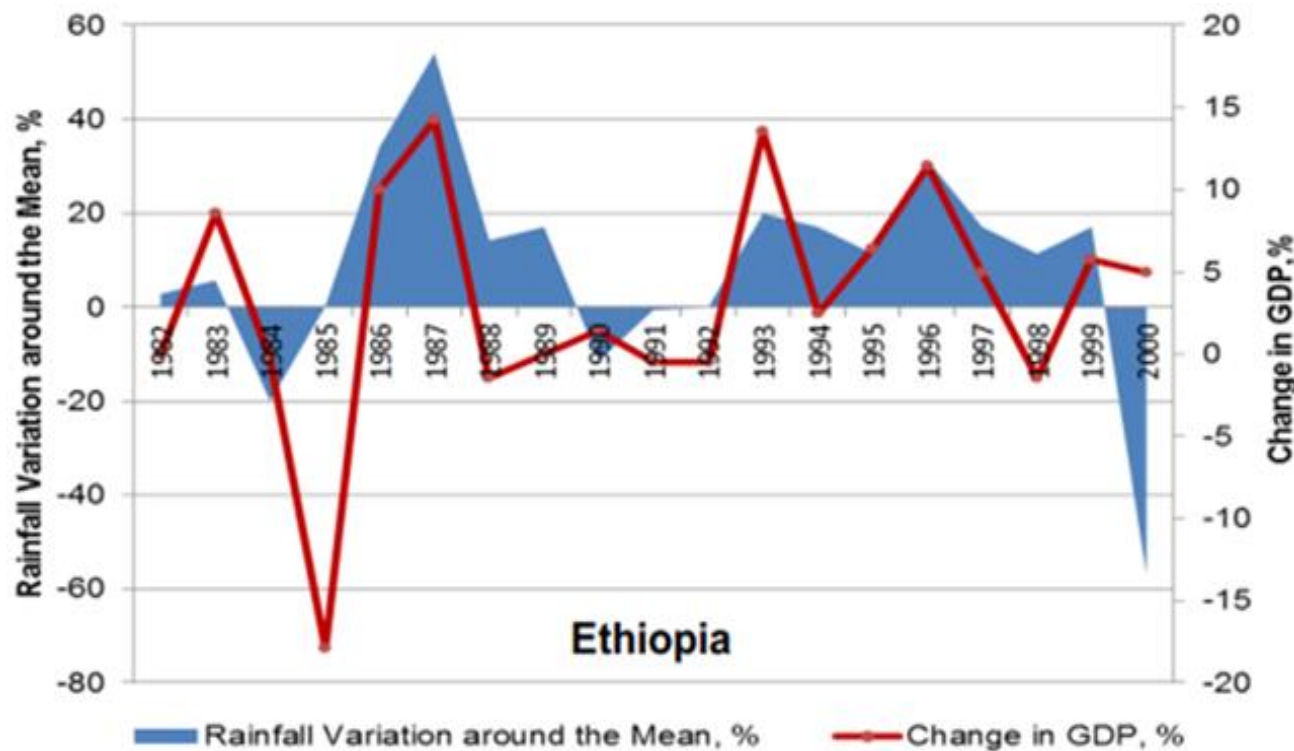

Fig 2:- Patterns in rainfall and GDP growth in Ethiopia (Evans, 2012).

In Africa, Ethiopia suffered the most accounted for $39 \%$ of all affected people of the continent from 1964 to 2006 (Shiferaw et al., 2014). Ethiopia has recently challenged three broad food scarcities and famines due to drought, in 1972/73, 1983/84, 2002/03, which has cost many lives (Awulachew et al., 2005). Even recently, in October 2016, about 15 million people suffered from food insecurity (OCHA, 2016). Indeed, recurring drought events in the past led to massive loss of life and property, as well as people's displacement. Therefore, the risk of drought averts farmers from implementing lucrative technologies and practices that are perceived as risky, thereby creating a link that increases the susceptibility cycle and consumes the ability to overcome famine and poverty (Shiferaw et al., 2014).

\section{$>$ Flood}

Topographic features of Ethiopia, one of the largest nations in East Africa, have made the country highly exposed to floods and as a result damaged and harmed the life, economy, livelihoods, infrastructure, services, and health system (DPPA, 2007). Communities and households located in rural areas with underdeveloped road networks and limited access to markets, schools, and public services are more vulnerable. Consequently, their lives, assets, health, and future prosperity may be further compromised with the onset of floods and landslides (Evans, 2012). There are two types of floods in Ethiopia: flash floods and river floods. Flash floods are those that consist of excessive precipitation in the upper basins and downstream with huge intensity, speed, and power. Usually, they are unexpected and seemingly unnoticed. Therefore, such floods frequently cause a substantial fee; and as they pass through or along with humanoid settlements and mass of infrastructure, the impairment becomes particularly evident and destructive. Billi et al. (2013) testified that the entire country is likely to be exposed to flood hazards and that these may be related to climate change, strong monsoon rains, especially during the main rainy season. The event Dire Dawa city experienced in 2006 is a typical flash flood (DPPA, 2007).
Conversely, Ethiopia consists of twelve major river basins, whose drainage systems originate from centrally located plateaus and descend to the peripheral or outer plains. Indeed, most of the flood devastations in Ethiopia are caused by rivers that overflow or erupt their banks and submerge low-lying plains. The flood that attacked the Southern Oromia Zone and East Shewa (mainly Dugeda Bora Woreda) zone in 2006 is a typical appearance of river floods. Flooding has been happening with erratic scale at various places and times (Bishaw, 2012). The magnitude of the flooding occurred for example, in 2006 was unprecedented (DPPA, 2007). Even recently, 2016, about 120,000 people have been displaced by floods in different regions of Ethiopia (OCHA, 2016).

\section{$>$ Soil erosion}

Soil erosion is one of the important intimidations to current and potential food production especially in the highlands of Ethiopia which covers $40 \%$ of Ethiopia's landmass and accounts for about $95 \%$ of all cultivated land. Nearly $88 \%$ of the humanoid population of the country lives there, with $70 \%$ of the total livestock population. It is also considered that more than $90 \%$ of the viable activities in the country are concentrated in the mountainous regions (Teklewold and Köhlin, 2011). Fast population growth, farming on steep slopes, deforestation, and overgrazing are the main factors that hasten soil erosion in Ethiopia. Amongst the sub-Saharan countries, there is a high level of soil erosion in Ethiopia (Nigussie et al., 2017). In this context, sheet and rill erosion all over the country, gullying in mountainous regions and wind erosion in the Rift Valley and surrounding plains are defined as the most important existing geomorphic processes in Ethiopia. Tillage erosion and landslides are more rarely occurred forms degradations. For the past few years, national and worldwide institutions have been trying to support improved land use and recommend soil and water protection technologies to stop soil erosion and diversify people's income sources (Haregeweyn et al., 2015). However, there has been a 
comparatively low level of success in this regard in the wider area (Haregeweyn et al., 2015; Nigussie et al., 2017).

On the other hand, the yearly amount of soil loss due to erosion, in the country, is higher than the annual soil formation rate (Nigussie et al., 2017). The renewal process of natural soil in the highland regions is 10 times slower than in different forms. Topsoil loss in the highland regions is estimated to be $300 \mathrm{Mg} \mathrm{ha}^{-1}$ year $^{-1}$ (Tesfaye et al., 2014). On the contrary, the annual amount of soil loss in agricultural lands throughout the country has been reported to be in the range of $20 \mathrm{Mgha}^{-1}$ up to $42 \mathrm{Mg} \mathrm{ha}^{-1}$ (Haregeweyn et al., 2015; Nigussie et al., 2017). If this action stays long, there will not be adequate soil amount accessible to maintain plant life. Soils with low-nutrients such as nitrogen and phosphorus will remain to grow crops. Pimentel (2006) reported that soil erosion can decrease crop yield by up to $30 \%$. On the other hand, Debele and Abdulahi (2009) reported that Ethiopia losses over 1.5 billion tons of soil annually from the mountainous areas which could have added around 1.5 million tons of grain to the country`s yield. The above facts indicated that soil loss is a very important risk to the food safety of the Ethiopian people; however, it could be reduced through adequate and integrative water and land management intervention (Nigussie et al., 2017).

\section{$>$ Salinity and sodicity}

Soil salinity is the main problem of crop production and causes a significant amount of land to be abandon. Salinity is also considered to be the main factor affecting crop formation in dry areas. The total soil area affected by salt in Ethiopia is approximately 11 million hectares; about half of these soils are saline and the remaining half are saline-sodic and sodic soils (Gebrehiwot, 2018). According to Abraha and Yohannes (2013), the amount of land affected by salinity had increased from 6 to $16 \%$ of the entire land area of the country. This harms the seedling growth of the majority of crops, by making an osmotic pressure in the rhizosphere which hinders the sorption of water or cause toxic effects due to $\mathrm{Na}$ and $\mathrm{Cl}$. For example, the Awash basin is considered to be an area where salinity is a serious problem in its countless large and mediumsized irrigation fields, including the Amibara irrigation project in Central Awash, Metahara sugar cane plantations in Upper Awash and Tendaho sugar cane plantations in the district of Dubti (Debele and Abdulahi, 2009; Gebrehiwot, 2018). A significant share of the central and lower portions of the catchments are also salty or sodic or possibly exposed to these important problems (Asmamaw et al., 2018).
Inadequate use of irrigation water combined with no proper drainage scheme can lead to a ground-water rise, salinity, and significant losses of crop harvests which eventually led to the rejection of a significant amount of productive lands. Likewise, the salinity and waterlogging issues continue in various districts where farmers use disproportionate irrigation water and were farmers and irrigation subdivisions fail to participate in suitable drainage practices (Gebrehiwot, 2018).

\section{$>$ Poor water resource management and irrigation policies}

The water resources of Ethiopia look substantial and there are twelve river basins with expected surface water amount of 122 billion cubic meters per year (Evans, 2012; UN-WATER/WWAP, 2004). There is also a significant amount of rainfall in the country with spatiotemporal variability. The surface area of natural lakes is approximately $7,500 \mathrm{~km}^{2}$. Groundwater resources estimated at 2.6 billion $\mathrm{m}^{3}$ (UN-WATER/WWAP, 2004). However, the population remains without proper water infrastructure and the country is one of the least irrigated (Eneyew et al., 2014), with less than $5 \%$ of the estimated potential 5.3 million ha of irrigable land. Most of them are traditional and public (World Bank, 2006).

Indeed, water shortage does not mean just physical water insufficiency; there is, however, also economic water scarceness, which is common in Ethiopia, and could be alleviated through the implementation of appropriate irrigation and water storage techniques (Eneyew et al., 2014). However, the lack of managerial or economical capacities led the country to water scarcity (Haileslassie et al., 2016). On the contrary, Ethiopia is likely to face physical water scarcity, stress, and susceptibility by 2025 (Figure. 3) signifying that water resources are very reliant on, and affected by, climate (Shiferaw et al., 2014). Different analyses have found that although Ethiopia has a policy and legal agenda that supports integrated water resource management (IWRM), its application is inadequate. Besides, official roles are not adequately wellexpressed, and there are no well-organized hierarchies for IWRM, particularly at the regional and district levels. In general, they lack sufficient monetary, humanoid and technological resources to carry out their duties. The links between figures/information and policymaking and preparation procedures were found to be weak or in some cases not available. The existing very low level of hydraulic infrastructure and inadequate water resources administration capacity challenge efforts to manage inconsistency. These conditions almost leave Ethiopia's economic presentation captive to its hydrology (World Bank, 2006). 
ISSN No:-2456-2165

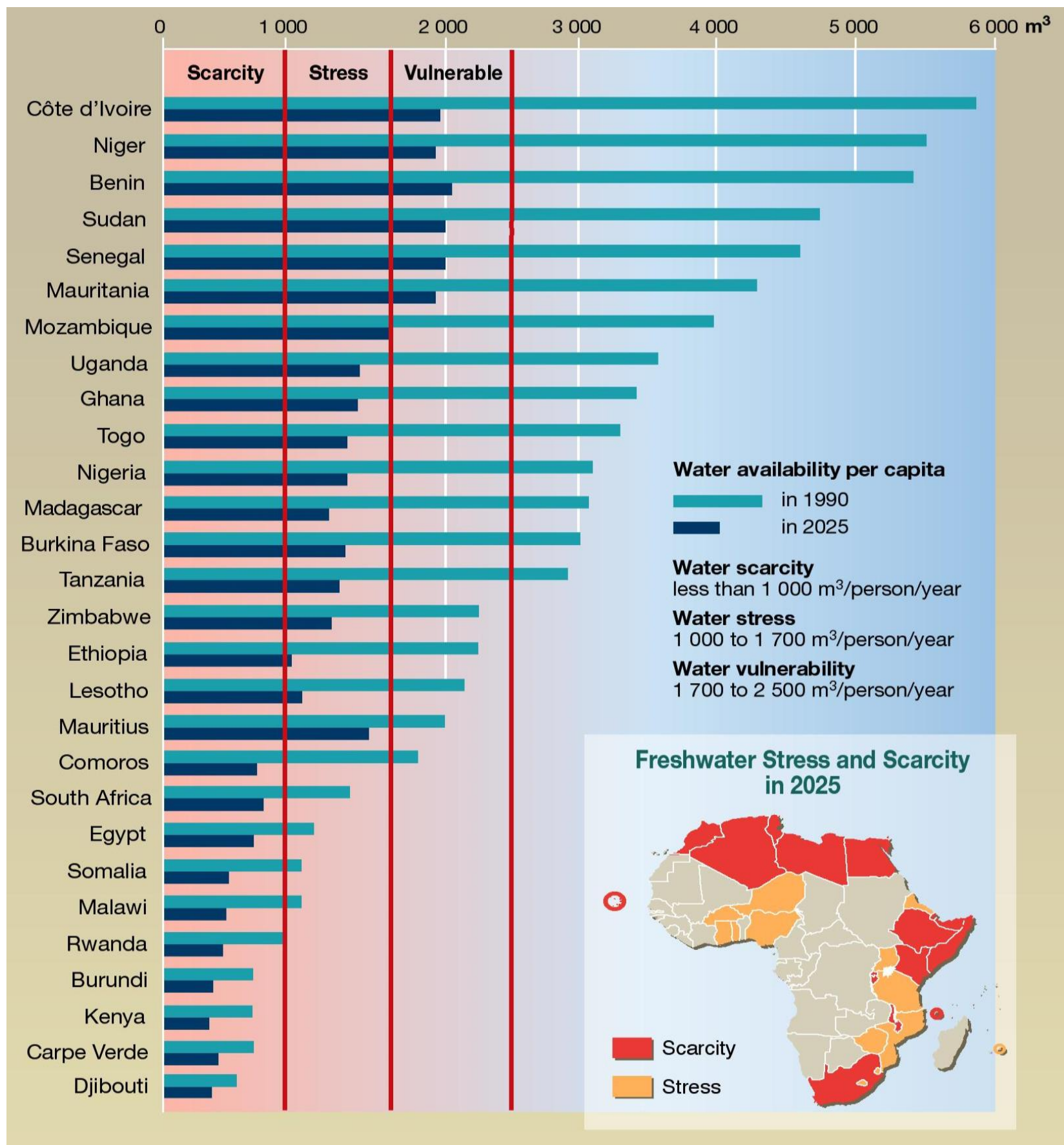

Fig 3:- Per capita water availability in African countries in the year 1990 and 2025 (Shiferaw et al., 2014)

With the extension of outdated irrigation programs in Ethiopia, there have been many organizations in various irrigation programs, especially in the last decade (e.g. Meki, May, Nigus, Wukro/Hayelom, and Hare/Waro schemes are shown in Figure. 4) (Haileslassie et al., 2016). Yet, most of these programs are inadequate in terms of capital and technological capacities and their performance is disappointing (Yami, 2013). Public irrigation financing in the country has little emphasis on operation and repair and long-term inspecting matters (Haileslassie et al., 2016). Consequently, there are difficulties both in water resources management and service delivery of the region (Pascual-Ferrer et al., 2014). Moreover, most irrigation programs in Ethiopia do not have monitoring agenda in topics such as water charges, water rights, water conflict resolution, motivations for collaboration between the district, regional, and national levels of administration and encouragements for precise reportage of existing developments (Awulachew, 2010). 


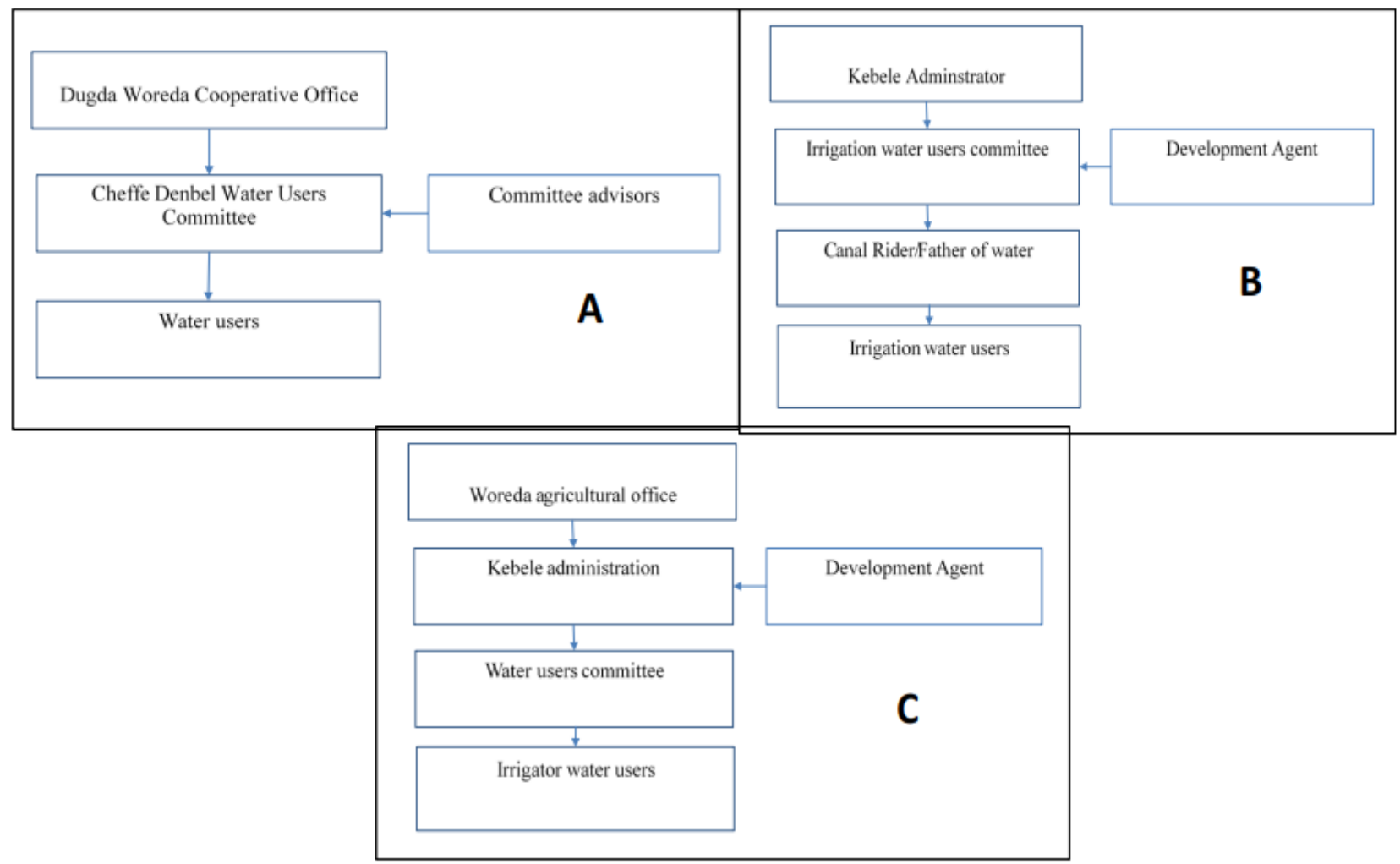

Fig 4:- Illustrations of the hierarchy of irrigation institutes: Meki association (A); May Nigus and Wukro/Hayelom association (B) and Hare/Waro association (C) (Haileslassie et al., 2016)

On the contrary, some indications around the world confirm that irrigation management of government interventions creates a weighty monetary responsibility on governments, and in some areas, its performance is unsatisfactory. Therefore, many countries in Asia and Latin America have been implementing irrigation management transfers (IMT) for more than twenty years (Haileslassie et al., 2016). A number of irrigation water management responsibilities have been devolved from state-run institutions to participating, independent and monetarily self-financing water user organizations in numerous countries (Feyisa, 2014). In this context, for example, Turkey has been successful and has found a good result of the transformation of irrigation water management from the government-run to the business enterprises. Turkey has made huge advancements in irrigation management institutes and strategies since the early 1990s (Haileslassie et al., 2016).

\section{INTEGRATED WATER MANAGEMENT FOR SMALLHOLDER'S ECONOMIC SUSTAINABILITY}

Impact of irrigation management for smallholder agriculture

Adopting a well-organized water usage practice will guarantee food safety, have a major impact on poverty reduction (Evans, 2012; Nugusse, 2013). After the great hunger in 1984/85, Ethiopia emphasized the importance of small-scale irrigation. Farmers and public-based smallscale irrigation were supported by training and supervision through implementing up-to-date skills, reintegration, and the advancement of outdated systems to assure food security (ADF, 2001). Mostly practice surface irrigation methods in the country are channel, basin and border. Although some farmers and organizations use pumps, gravity supply of irrigation is the most frequently used for water abstraction. Another important change in the landuse of some farmers is the introduction of water harvesting ponds (e.g.) introduced in 2009 in Kete village (Figure 5) (Rosell, 2014). 


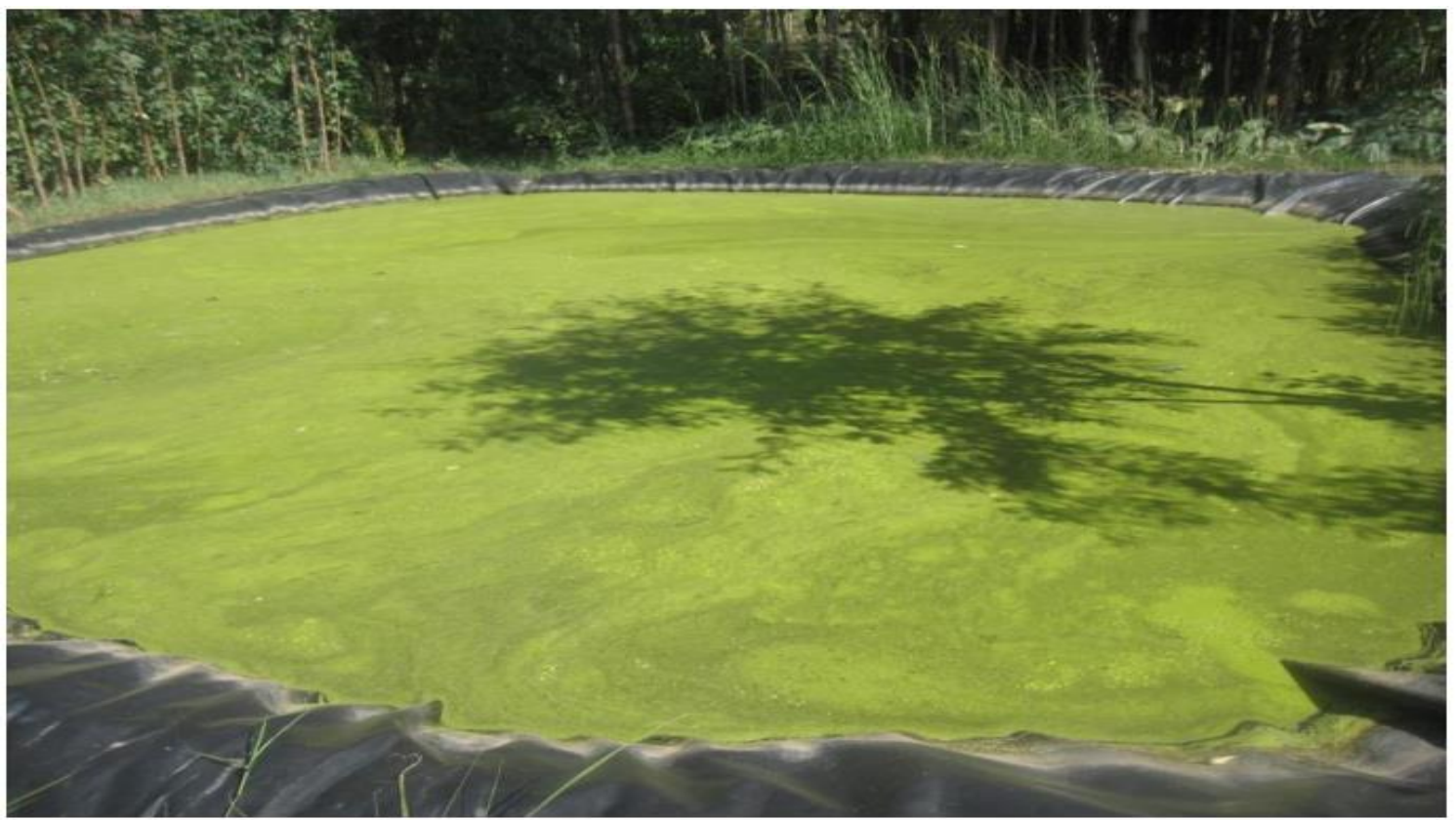

Fig 5:- Photo of a water harvesting pond in Kete kebele, Ethiopia (Rosell, 2014).

In mountainous areas, the possibility of using small scale irrigation is prevented due to very little river flow in the dry season, and during this time the only way to irrigate peasant land is to build storage tanks (ADF, 2001). An increasing number of small-scale farmers in Ethiopia are trying to increase crop yields, diversify crop production and livelihoods, and increase their income through improved water management activities (Awulachew, 2010; James and Maryam, 2014). In addition, the small-scale irrigation sector provides food safety for some farmers, by improving their income, health and nutrition. For example, in centralnorth, eastern, and southeastern parts of Ethiopia, cereals, (mostly maize, sorghum, wheat and barley), industrial crops like (sugarcane, vegetable, cotton), root crops (potato and sweet potato) and fruits are mainly produced by traditional water harvesting practices (FAO, 2015). In the past, studies have emphasized that agricultural water expansion is crucial for increasing smallholder income because irrigation can help growers raise crop yields and product diversity, and extend their growing seasons (Bacha et al., 2011; Dauda et al., 2009; FAO, 2011; Kuwornu and Owusu, 2012). Many households of Ethiopia have acknowledged the importance of small-scale irrigation in poverty reduction, regardless of all the limitations known.
In this context, James and Maryam (2014) state that smallholders in Ethiopia can expand and convert farming to marketable products such as fruit, cash crops and vegetables through small-scale irrigation.

Similarly, it has been revealed that small-scale irrigation users are better than non-irrigators in terms of food safety and other wellbeing determiners (Figure. 6) (Tadesse and Baihilu, 2017). In this regard, in Arab countries, there are examples of success in the cultivation of marketable agricultural produces such as tomatoes, peas, green peppers, groundnuts, maize, cucumbers and rape as a result of the building of 126 surfaces and 54 sprinkler irrigation systems (Singh et al., 2009). Besides, irrigation investment enabled farmers to increase the diversification of crops, and use of improved seed varieties and cultivation of high-value market-oriented products in India (Bhattarai et al., 2007), China (Huang et al., 2006) and Ghana (Kuwornu and Owusu, 2012). Another study by Chiza (2005) in Tanzania found that irrigation increased yield per hectare of rice, maize, tomato and onion from 1.5 to 4.1 , 1.1 to $3.3,2.0$ to 3.0 and 2.5 to 3.5 tons respectively in Rufiji basin, and from 2.0 to $5.3,1.1$ to $4.9,2.0$ to 4.0 and 2.5 to 4.0 tons respectively in the Pangani basin. 

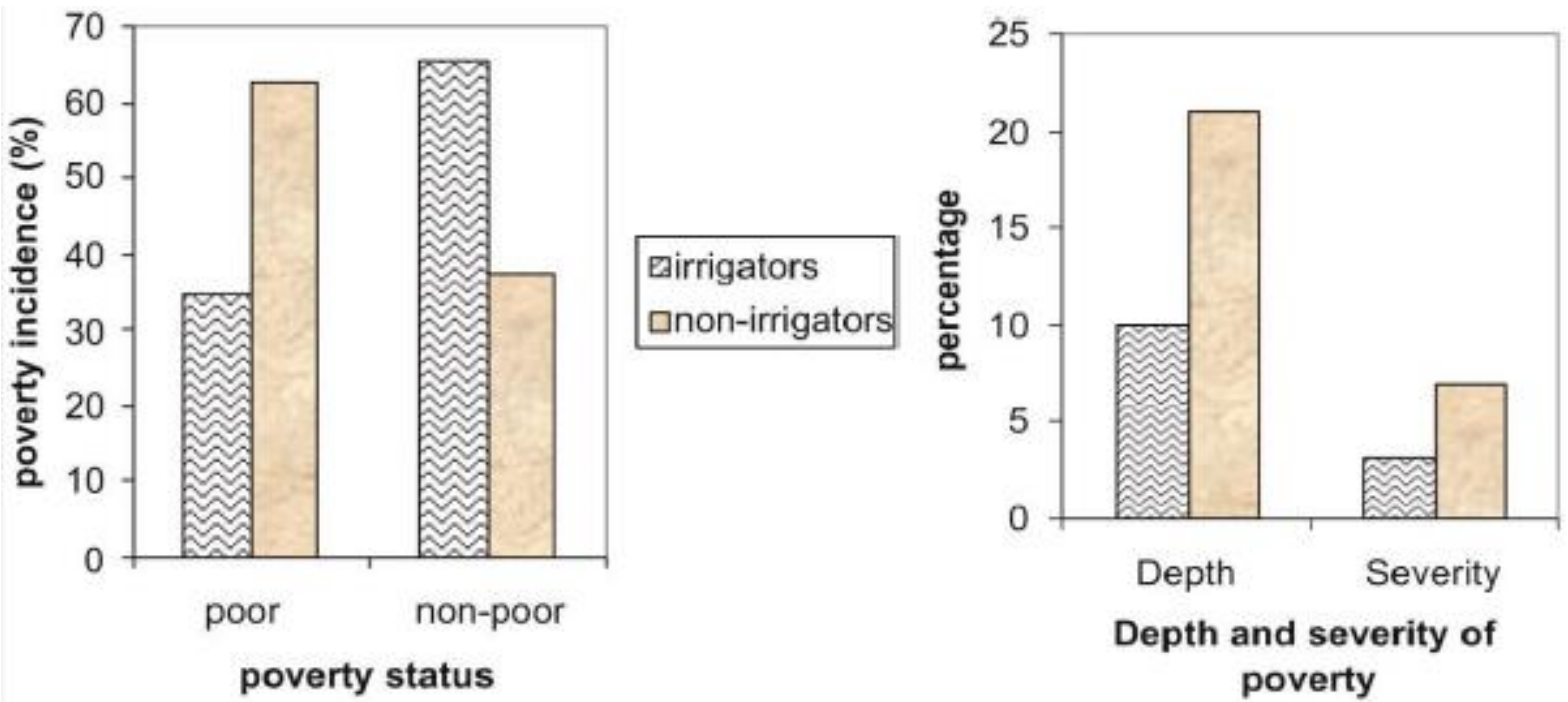

Fig 6:- Household food security status differentiated among irrigators and non-irrigators (Tadesse and Baihilu, 2017)

The irrigation segment can also grow domestic profits, reduce food charges, deliver on/off-farm employment and increase opportunities. This is confirmed by different studies for example in Ethiopia (Bacha et al., 2011), Nigeria (Dauda et al., 2009), Zimbabwe (Chazovachii, 2012) and Vietnam (Huang et al., 2006). Moreover, Hussain (2006) revealed that poverty incidence was minimized by 20 to $30 \%$ (in India) and 5 to $10 \%$ (in Pakistan) because of small scale irrigation. In addition, the study by Yihdego et al. (2015) in the Tigray region (Ethiopia) revealed that the production of the main crops including, teff, wheat, barley, gesho, sorghum and millet with small-scale irrigation has a remarkable optimistic outcome on domestic income. Although small-scale agricultural water management practices can potentially benefit hundreds of thousands of farmers in Ethiopia, its potential is not well-understood. The continuousness of the irrigation sector in the country has been a subject of discussion due to its unsatisfactory presentation in various aspects. Due to the multiple limitations faced by smallscale farmers, access to irrigation water by itself is not enough. Small-scale irrigators also need a wide variety of assistance activities (access to inputs, credit, and harvest/yield markets), data of agribusiness and safe land tenancy (MoFED, 2010).

\section{$>$ Impact of soil and water conservation for smallholder agriculture}

Indigenous water and land management techniques have been practiced for a long time in Ethiopia. However, administrative soil and water preservation strategies have only been important only since the 1970s (Osman and Sauerborn, 2001). The biggest management actions in the country were those that were carried out in a 'food-forwork program, mainly in the 1970s and 1980s. Terracing is widely used in the Ethiopian highlands, just as grass stripping, soil bunds, stone bunds, controlled grazing and alley cropping (Rosell, 2014). On the other hand, these activities in Ethiopia are usually inadequately documented and not measured by management consultants and officials. However, it is clear that the inclusion of local experiences in development work increases adaptation and acceptance in local socioeconomic settings (Haregeweyn et al., 2015). Investigations have specified that following the application of local water and soil preservation techniques, there was substantial growth in woody vegetation and riverbed stabilization due to low water discharge (Frankl et al., 2013)

Indeed, the effectiveness of these local conservation actions is affected by the moisture regime and by the age of the constructions (Haregeweyn et al., 2015). For example, soil and water conservation practices in the Ethiopian highlands will be more effective in reducing overflow and soil erosion in semi-arid Ethiopian mountainous areas but will work to a lesser extent in humid areas (Taye et al., 2015). Regarding the efficiency of these conservation practices, there are different views mainly on the exact type measurement, the type of agroecology, and the traditions in cost-benefit analysis. A study made by Haregeweyn et al. (2015) revealed that the application of stone bunds in Tigray, northern Ethiopia produced a $50 \%$ rate of return based on crop harvests and land productivity. In the same region, however, an assessment done by Nyssen et al. (2007) showed that the construction price of stone bund structures of various ages (3 to 21 years) is almost similar to typical growth in grain harvest with an increase in crop yield by $53 \%$. On the contrary, it has been confirmed that local conservation practices have long-term profits for users. In another scenario, the effectiveness of water and land management on soil aggregation, water penetration, biological and grain yield, groundwater recharging and reduction of flood risk has been reported (Haregeweyn et al., 2015).

According to many studies, local water and soil conservation activities not only affect crop yield growth but also affect externalities such as improvement in environmental services, water availability, soil loss, and precipitation regulation, improvement of soil fertility and carbon sequestration for microclimate adjustment (Mekuria et al., 2011). Therefore, in order to overcome the problems 
of climate change and soil loss in the Ethiopia, soil and water conservation, afforestation, preservation of trees, adequate irrigation systems, scientific water management techniques, and sustainable land management are defining mandates of various state programs (Wolka et al., 2013).

\section{CONCLUSION AND FUTURE LINE OF WORK}

It is clear that the country's plan to expand and promote irrigated farming and water management is predictable, given Ethiopia's agriculture-dependent economy, growing demand for food due to the growing population, the insufficiency of rain-fed agriculture, and climate change. The planned expansion target should be achieved in areas sensitive to drought, flooding and erosion and salinity problems. The literature studies mentioned in this review are an indication of the significance of water management (such as irrigation, preservation of available water bodies, expansion of new surface water and groundwater and others) in the country for increasing crop yield by regulating the aforementioned agricultural issues. It has been reviewed that small-scale agricultural water and soil conservation practices contribute to food safety in Ethiopia by increasing crop yields and diversifying crop production and income choices. Despite the country's moves to fight poverty through strongly supporting the irrigation developments, little progress has been registered in terms of actions on-the-ground and impact. Still, the country used only 5 to $10 \%$ of 5.3 million hectares of the total irrigable potential land. Limited human skills and capital, fragmented and small farmland, lack of technologies and financial resources, generally poor coordination of these with weak institutional set up were often the causes of inadequate success.

It can be concluded that integrated water management is notable for efficient and rewarding irrigated farming, which can help the country realize its intended agricultural advancements. The inevitable difficulties that can be encountered in the progression are related to the cost, equipment and skill in the design, use, procedure and maintenance of the systems. However, this can be solved by considering cost-effective technologies for the medium and large-scale irrigation plan. Extensive studies should be done to explore the productivity of irrigation, drainage systems and other skills in detail. In any case, proper attention should be paid to soil and water management. Among other measures, it is important to use the salt and drought-tolerant crop genotype, which should be implemented by all stakeholders to save water at all levels. Finally, administrations and other stakeholders are required to fulfill the necessary monetary promises and to design and implement good policies on effective water management systems.

\footnotetext{
$>$ Disclosure statement

No potential conflict of interest was reported by the
} authors.

\section{ORCID}

Mulat Asmamaw Admasie http://orcid.org/0000-00024774-7860

Ahmet Kurunc http://orcid.org/0000-0002-1983-8415

\section{REFERENCES}

[1]. Abraha, B., Yohannes, G. (2013). The role of seed priming in improving seedling growth of maize (Zea mays L.) under salt stress at field conditions. Agric. Sci. 4 , 666-672. https://doi.org/http://dx.doi.org/10.4236/as.2013.4120 89

[2]. ADF (2001). Koga irrigation and watershed management project, Appraisal Report, African Development Fund.

[3]. Asmamaw, M., Haile, A., Abera, G. (2018). Characterization and classification of salt-affected soils and irrigation water in Tendaho sugarcane production farm, North-Eastern Rift Valley of Ethiopia. African J. Agric. Res. 13, 403-411. https://doi.org/10.5897/ajar2018.12988

[4]. Awulachew, S.B. (2010). Irrigation potential in Ethiopia: Constraints and opportunities for enhancing the system, International Water Management Institute.

[5]. Awulachew, S.B., Merrey, D.J., Kamara, A.B., Van Koppen, B., Penning de Vries, F., Boelee, E., Makombe, G. (2005). Experiences and opportunities for promoting small-scale/micro irrigation and rainwater harvesting for food security in Ethiopia (No. Working paper 98).

[6]. Bacha, D., Namara, R., Bogale, A., Tesfaye, A. (2011). Impact of small-scale irrigation on household poverty: empirical evidence from the ambo district in Ethiopia. Irrig. Drain. 60, 1-10. https://doi.org/10.1002/ird.550

[7]. Bhattarai, M., Barker, R., Narayanamoorthy, A. (2007). Who benefits from irrigation development in India? Implication of irrigation multipliers for irrigation financing. Irrig. Drain. 56, 207-225. https://doi.org/10.1002/ird.309

[8]. Billi, P., Alemu, Y.T., Ciampalini, R. (2015). Increased frequency of flash floods in Dire Dawa, Ethiopia: Change in rainfall intensity or human impact? Nat. Hazards 76, 1373-1394. https://doi.org/10.1007/s11069-014-1554-0

[9]. Bishaw, K. (2012). Application of GIS and remote sensing techniques for flood hazard and risk assessment: the case of Dugeda Bora Woreda of Oromiya Regional State, Ethiopia, in: 2012 Berlin Conference on the Human Dimensions of Global Environmental Change. pp. 1-17.

[10]. Chazovachii, B. (2012). The impact of small scale irrigation schemes on rural livelihoods: the case of Panganai Irrigation Scheme Bikita District Zimbabwe. J. Sustain. Dev. Africa 14, 217-231.

[11]. Chiza, C.K. (2005). The role of irrigation in agriculture, food security and poverty reduction, in: The 3rd Annual Engineer's Day. Dar es Salaam. 
[12]. Dauda, T.O., Asiribo, O.E., Akinbode, S.O., Saka, J.O., Salahu, B.F. (2009). An assessment of the roles of irrigation farming in the millennium development goals. African J. Agric. Res. 4, 445-450.

[13]. Debele, T., Abdulahi, B. (2009). Sustainable land management and agricultural practices research and extension in Ethiopia, in: United Nations Expert Group Meeting on SLM and AP,. Gothenburg, Sweden, p. 37.

[14]. DPPA (2007). Regional summary of flood impact assessment of early warning department (EWD).

[15]. Eneyew, A., Alemu, E., Ayana, M., Dananto, M. (2014). The role of small scale irrigation in poverty reduction. J. Dev. Agric. Econ. 6, 12-21. https://doi.org/10.5897/jdae2013.0499

[16]. Evans, A. (2012). Resources, risk and resilience: scarcity and climate change in Ethiopia. New York University: Center on International Cooperation.

[17]. FAO (2015). Ethiopia: Irrigation market brief. Food and Agricultural Organization of the United Nations, Rome.

[18]. FAO (2011). State of food insecurity in the world 2011: how does international price volatility affect domestic economies and food security, Food and Agricultural Organization of the United Nations, Rome.

[19]. Feyisa, A.A. (2014). Irrigation water users association formation and development manual. Japan International Cooperation Agency (JICA) \& Oromia Irrigation Development Authority (OIDA).

[20]. Frankl, A., Poesen, J., Haile, M., Deckers, J., Nyssen, J. (2013). Quantifying long-term changes in gully networks and volumes in dryland environments: The case of Northern Ethiopia. Geomorphology 201, 254 263. https://doi.org/10.1016/j.geomorph.2013.06.025

[21]. Gebrehiwot, K.A. (2018). A review on waterlogging, salinization and drainage in Ethiopian irrigated agriculture. Sustain. Water Resour. Manag. 4, 55-62. https://doi.org/10.1007/s40899-017-0121-8

[22]. Georgis, K. (2014). Agricultural and pastoral technologies and practices for climate change adaptation in lowland dryland areas of Ethiopia, Integrated Drylands Management in Ethiopia. Proceedings of the High Level Policy Forum 6 - 7 March 2014, Semera, Afar National Regional State.

[23]. Haileslassie, A., Hagos, F., Agide, Z., Tesema, E., Hoekstra, D., Langan, S. (2016). Institutions for irrigation water management in Ethiopia: Assessing diversity and service delivery, LIVES Working Paper 17. Nairobi, Kenya.

[24]. Haregeweyn, N., Tsunekawa, A., Nyssen, J., Poesen, J., Tsubo, M., Meshesha, D.T., Schütt, B., Adgo, A., Tegegne, F. (2015). Soil erosion and conservation in Ethiopia: A rewiew. Prog. Phys. Geogr. 39, 750-774. https://doi.org/10.1177/0309133315598725

[25]. Huang, Q., Rozelle, S., Lohmar, B., Huang, J., Wang, J. (2006). Irrigation, agricultural performance and poverty reduction in China. Food Policy 31, 30-52. https://doi.org/10.1016/j.foodpol.2005.06.004

[26]. Hussain, M., Hussain, Z., Ashfaq, M. (2006). Impact of small scale irrigation schemes on poverty alleviation in marginal areas of Punjab, Pakistan. Int. Res. J. Financ. Econ. 6, 193-200.

[27]. James, B., Maryam, M.O. (2014). Small-scale irrigation and household wages relationship: Proof from Deder district, Ethiopia. Int. J. Irrig. Water Manag. 2014, 1-11.

[28]. Kuwornu, J.K.M., Owusu, E.S. (2012). Irrigation access and per capita consumption expenditure in farm households: Evidence from Ghana. J. Dev. $\begin{array}{lll}\text { Agric. Econ. 78-92. } & \text { 4, }\end{array}$ https://doi.org/10.5897/jdae11.105

[29]. Makombe, G., Namara, R.E., Awulachew, S.B., Hagos, F., Ayana, M., Kanjere, M. (2017). An analysis of the productivity and technical efficiency of smallholder irrigation in Ethiopia. Water SA 43, 4857. https://doi.org/10.4314/wsa.v43i1.08

[30]. Mekuria, W., Veldkamp, E., Corre, M.D., Haile, M. (2011). Restoration of ecosystem carbon stocks following exclosure establishment in communal grazing lands in Tigray, Ethiopia. Soil Sci. Soc. Am. J. 75, 246-256. https://doi.org/10.2136/sssaj2010.0176

[31]. MoFED (2010). The Federal Democratic Republic of Ethiopia. Growth and Transformation Plan, Ministry of Finance and Economic Development. Addis Ababa.

[32]. Naumann, G., Barbosa, P., Garrote, L., Iglesias, A., Vogt, J. (2014). Exploring drought vulnerability in Africa: An indicator based analysis to be used in early warning systems. Hydrol. Earth Syst. Sci. 18, 15911604. https://doi.org/10.5194/hess-18-1591-2014

[33]. Nigussie, Z., Tsunekawa, A., Haregeweyn, N., Adgo, E., Nohmi, M., Tsubo, M., Aklog, D., Meshesha, D.T., Abele, S. (2017). Farmers' perception about soil erosion in Ethiopia. L. Degrad. Dev. 28, 401-411. https://doi.org/10.1002/ldr.2647

[34]. Nugusse, Z.W. (2013). Food security through small scale irrigation: case study from Northern Ethiopia. MSc Thesis, International Master of Science on Rural Development, Ghent University.

[35]. Nyssen, J., Poesen, J., Gebremichael, D., Vancampenhout, K., D'aes, M., Yihdego, G., Govers, G., Leirs, H., Moeyersons, J., Naudts, J., Haregeweyn, N., Haile, M., Deckers, J. (2007). On-site evaluation of stone bunds to control soil erosion on cropland in Northern Ethiopia. Soil Tillage Res. 94, 151-163. https://doi.org/10.1016/j.still.2006.07.011

[36]. OCHA (2016). El niño: Overview of impact, projected humanitarian needs and response, UN Office for the Coordination of Humanitarian Affairs.

[37]. Osman, M., Sauerborn, P. (2001). Soil and water conservation in Ethiopia. J. Soils Sediments 1, 117123. https://doi.org/10.1007/bf02987717

[38]. Pascual-Ferrer, J., Pérez-Foguet, A., Codony, J., Raventós, E., Candela, L. (2014). Assessment of water resources management in the Ethiopian Central Rift Valley: environmental conservation and poverty reduction. Int. J. Water Resour. Dev. 30, 572-587. https://doi.org/10.1080/07900627.2013.843410

[39]. Pimentel, D. (2006). Soil erosion: A food and environmental threat. Environ. Dev. Sustain. 8, 119137. https://doi.org/10.1007/s10668-005-1262-8 
[40]. Rosell, S. (2014). Rainfall variability, soils and land use changes in the highlands of Ethiopia. Doctoral Thesis A148, Department of Earth Sciences, University of Gothenburg.

[41]. Shiferaw, B., Tesfaye, K., Kassie, M., Abate, T., Prasanna, B.M., Menkir, A. (2014). Managing vulnerability to drought and enhancing livelihood resilience in sub-Saharan Africa: Technological, institutional and policy options. Weather Clim. Extrem. 3, 67-79. https://doi.org/10.1016/j.wace.2014.04.004

[42]. Singh, A.K., Rahman, A., Sharma, S.P., Upadhyaya, A., Sikka, A.K. (2009). Small holders' irrigationproblems and options. Water Resour. Manag. 23, 289-302. https://doi.org/10.1007/s11269-008-9275-3

[43]. Stokes, L., Scozzaro, A.T., Haller, J. (2010). The food crisis in Ethiopia and Egypt: Constrasting hydrological and economic barriers to development. Cons. J. Sustain. Dev. 3, 117-138.

[44]. Tadesse, M., Baihilu, B. (2017). Review on participatory small-scale irrigation schemes and small-scale rainwater harvesting technology development and its contribution to household food security in Ethiopia. Int. J. Water Resour. Environ. Eng. 9, 54-63. https://doi.org/10.5897/ijwree2016.0700

[45]. Taye, G., Poesen, J., Vanmaercke, M., Van Wesemael, B., Martens, L., Teka, D., Nyssen, J., Deckers, J., Vanacker, V., Haregeweyn, N., Hallet, V. (2015). Evolution of the effectiveness of stone bunds and trenches in reducing runoff and soil loss in the semi-arid Ethiopian highlands. Zeitschrift für Geomorphol. 59, 477-493. https://doi.org/10.1127/zfg/2015/0166

[46]. Teklewold, H., Köhlin, G. (2011). Risk preferences as determinants of soil conservation decisions in Ethiopia. J. Soil Water Conserv. 66, 87-96. https://doi.org/10.2489/jswc.66.2.87

[47]. Tesfaye, A., Negatu, W., Brouwer, R., van der Zaag, P. (2014). Understanding soil conservation decision of farmers in the Gedeb watershed, Ethiopia. L. Degrad. Dev. 25, 71-79. https://doi.org/10.1002/ldr.2187

[48]. UN-WATER/WWAP (2004). National water development report for Ethiopia. Addis Ababa.

[49]. Wolka, K., Moges, A., Yimer, F. (2013). Farmers' perception of the effects of soil and water conservation structures on crop production: The case of Bokole watershed, Southern Ethiopia. African J. Environ. Sci. Technol. 7, 990-1000. https://doi.org/10.5897/AJEST2013.1529

[50]. World Bank (2006). Ethiopia: Managing water resources to maximize sustainable growth. Washington, DC.

[51]. Worldometers (2019). Ethiopia population [WWW Document]. URL http://www.worldometers.info/worldpopulation/ethiopia-population/ (accessed 2.21.19).

[52]. Yami, M. (2013). Sustaining participation in irrigation systems of Ethiopia: what have we learned about water user associations? Water Policy 15, 961-984. https://doi.org/10.2166/wp.2013.031
[53]. Yihdego, A. (2015). The impact of small - scale irrigation on income of rural farm households: Evidence from Ahferom Woreda in Tigray, Ethiopia. Int. J. Bus. Econ. Res. 4, 217-228. https://doi.org/10.11648/j.ijber.20150404.14

[54]. Yihdego, T.G., Ghosal, S. (2016). Theimpact of small scale irrigation on household income in Bambasi Woreda, Benishangul-Gumuz Region, Ethiopia. Int. J. Sci. Res. Publ. 6, 400-406. 